\title{
Changes in sedimentation trends in SW Iberia Holocene estuaries (Spain)
}

\author{
J. Lario ${ }^{\mathrm{a}, *}$, C. Zazo ${ }^{\mathrm{b}}$, J.L. Goy ${ }^{\mathrm{c}}$, C.J. Dabrio ${ }^{\mathrm{d}}$, F. Borja ${ }^{\mathrm{e}}$, P.G. Silva ${ }^{\mathrm{f}}$, F. Sierro ${ }^{\mathrm{c}}$, \\ A. González ${ }^{\mathrm{c}}$, V. Soler ${ }^{\mathrm{g}}, \mathrm{E}$. Yll ${ }^{\mathrm{h}}$ \\ a Area de Geodinámica Externa, Facultad de Ciencias del Medio Ambiente, Universidad de Castilla-La Mancha, 45071 Toledo, Spain \\ ${ }^{\mathrm{b}}$ Departamento de Geología, Museo Nacional de Ciencias Naturales, CSIC, clJose Gutierrez Abascal, 2, 28006 Madrid, Spain \\ ${ }^{\mathrm{c}}$ Departamento de Geología, Universidad de Salamanca, 37008 Salamanca, Spain \\ ${ }^{\mathrm{d}}$ Departamento de Estratigrafia, Facultad de Ciencias Geológicas, Universidad Complutense, 28040 Madrid, Spain \\ ${ }^{\mathrm{e}}$ Area de Geografia Física, Facultad de Humanidades. Avda. Fuerzas Armadas, Universidad de Huelva, 21007 Huelva, Spain \\ ${ }^{\mathrm{f}}$ Departamento de Geología, Universidad de Salamanca, E.U. Politécnica de Avila, 05003 Avila, Spain \\ ${ }^{\mathrm{g}}$ Instituto de Productos Naturales y Agrobiología, CSIC, Avenida Astrofisico Francisco Sánchez, 38206 La Laguna, Tenerife, Spain \\ ${ }^{\mathrm{h}}$ Unitat de Botánica, Departamento de Biología Animal, Vegetal i Ecología, Universitat Autónoma, 08193 Barcelona, Spain
}

Received 20 February 2002; accepted 20 February 2002

\begin{abstract}
An analysis of sedimentation rates during the Holocene in estuaries in the southwestern coast of the Iberian Peninsula using depth/age diagrams reveals the existence of two distinct phases. The first, between ca. 10,000 and $6500 \mathrm{Cal} \mathrm{BP}$, still in the transgressive phase, yields values of sedimentation rates of $5 \mathrm{~mm} / \mathrm{yr}$. The second phase extends after the maximum transgressive (ca. $6500 \mathrm{Cal} \mathrm{BP}$ ) until the present, with sedimentation rates of $1.5-2 \mathrm{~mm} / \mathrm{yr}$. These results support the idea that marine sedimentation began during the transgressive phase and continued during the highstand phase, far beyond the time of the transgressive maximum, as postulated in some previous papers.
\end{abstract}

\section{Introduction}

During recent years several studies approached the evolution of the southwestern coast of the Iberian Peninsula during the Holocene. Some of them focused on the evolution of spit barrier systems (Zazo et al., 1994, 1996; Lario et al., 1995; Lario, 1996; RodríguezRamírez et al., 1996), whereas other papers studied the sedimentary infill of the Flandrian estuaries (Dabrio et al., 1995, 1999, 2000; Goy et al., 1996; Lario, 1996; Pendón et al., 1998; Borrego et al., 1999). These studies used the maximum superficial extension of the open estuaries to date the age of the transgressive maximum at ca. 6500-6000 yr BP (Zazo et al., 1994). They also showed that the filling of the estuaries began during the Holocene transgression, coeval to a fast sea-level rise. Therefore, the filling continued after the transgressive maximum during the highstand phase that extends to

\footnotetext{
*Corresponding author.

E-mail address: lario@amb-to.uclm.es (J. Lario).
}

the present (Goy et al., 1996; Lario, 1996; Dabrio et al., 1999, 2000).

We have carried out an analysis of sedimentation rates during the whole phase of infilling in three estuaries of the southwestern coast of Spain in the Iberian Peninsula (Fig. 1) that contributes to refine the available data regarding their depositional trends. As summarised in Dabrio et al. (2000), the first marine influence in the estuaries during the last postglacial transgression occurred at ca.10,000 yr BP. After the maximum flooding (ca. $6500 \mathrm{yr}$ BP) the rate of eustatic rise decreased dramatically, and the estuarine filling followed a two-fold pattern governed by the progressive change from vertical accretion to lateral (centripetal) progradation.

A database of radiocarbon data in the estuaries formed using the available figures from previous papers (Table 1) allows the construction of diagrams that plot calibrated ages ( $x$-axis) versus depth of samples in the core (y-axis). Therefore the diagrams can be used for comparing the results in the three estuaries (Fig. 2). 
Table 1

Radiocarbon data

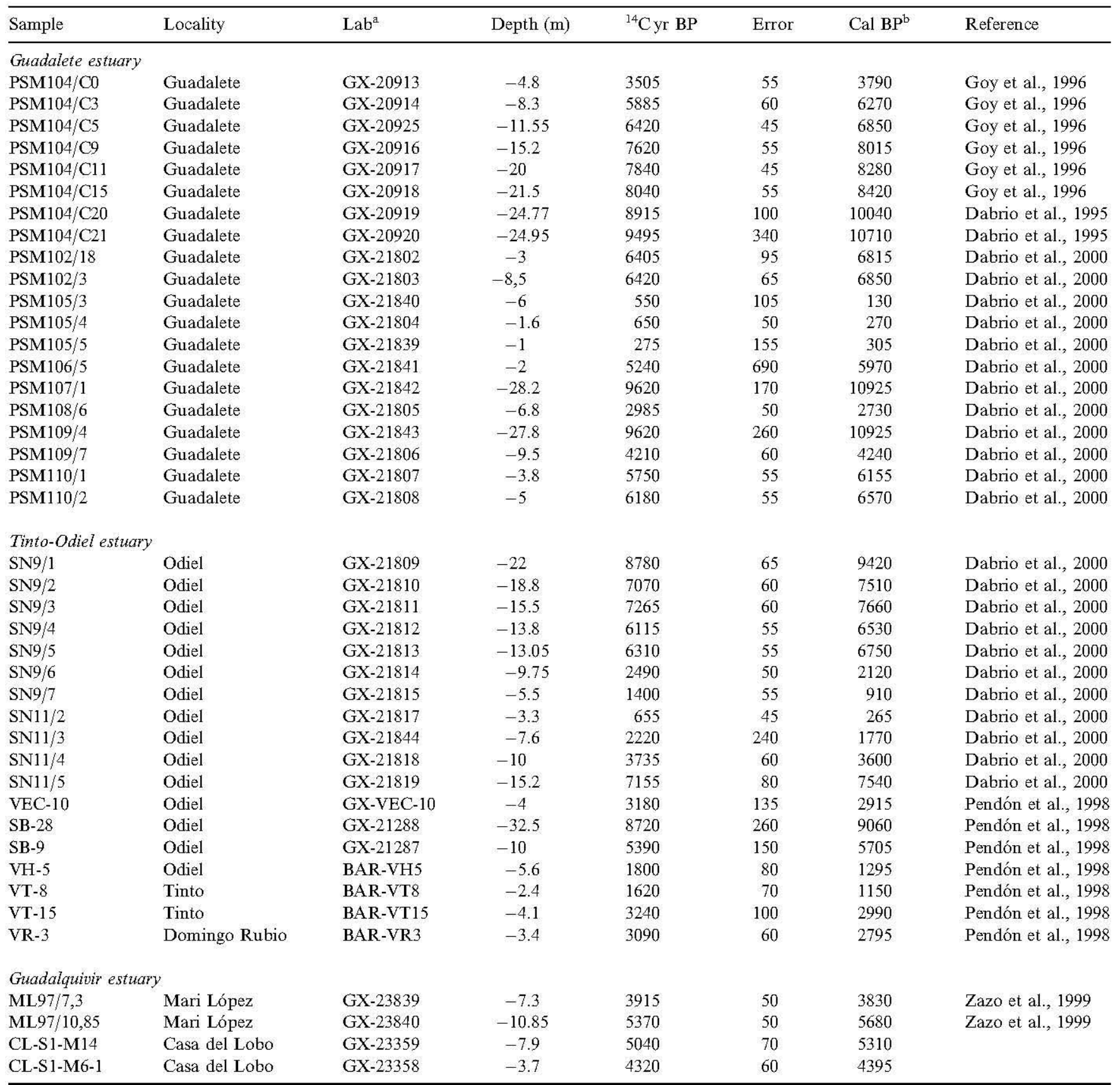

${ }^{\mathrm{a}}$ Laboratories Code: GX-Geochron Laboratories, Massachusetts, USA; BAR-Barcelona, Spain.

${ }^{\mathrm{b}}$ Calibrated with the Programme CALIB 4.2, Stuiver and Reimer, 1993; Stuiver et al., 1998.

almost continuous record of the Late Pleistocene and Holocene sequence.

We have plotted the data of the Holocene estuary fill in a depth/age diagram (Fig. 2a). The diagram shows that until near $6500 \mathrm{Cal} \mathrm{BP}$ the sedimentation rates exceed $3 \mathrm{~mm} / \mathrm{yr}$ and, even in the case of the SB core (Pendón et al., 1998), rates of $5 \mathrm{~mm} / \mathrm{yr}$ are surpassed. This is understandable since this core is located in an external zone of the estuary, where the pre-Flandrian relief (produced as a result of the incised valley topography developed during the Last Glacial sea-level fall) left enough accommodation space.

This result indicates that the rate of sea-level rise should be higher than $3 \mathrm{~mm} / \mathrm{yr}$, at least between 10,000 and $6500 \mathrm{Cal} \mathrm{BP}$. The diagram also shows that, after $6500 \mathrm{Cal} \mathrm{BP}$, sedimentation rates decreased to $1 \mathrm{~mm} / \mathrm{yr}$ in all the cores, suggesting values of sea-level rates lower than this figure. This is in agreement with the 
Tinto-Odiel estuary

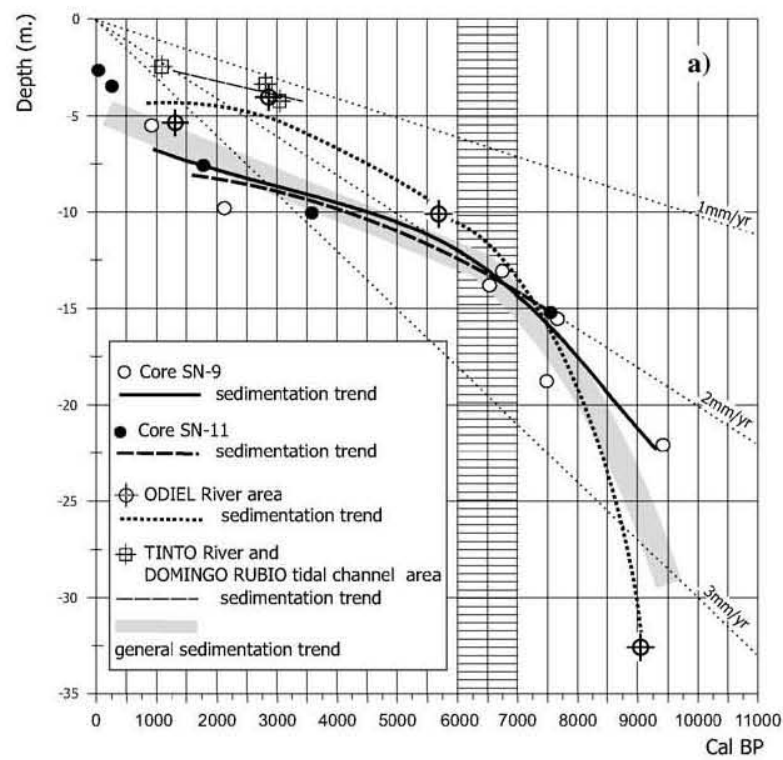

Guadalquivir estuary

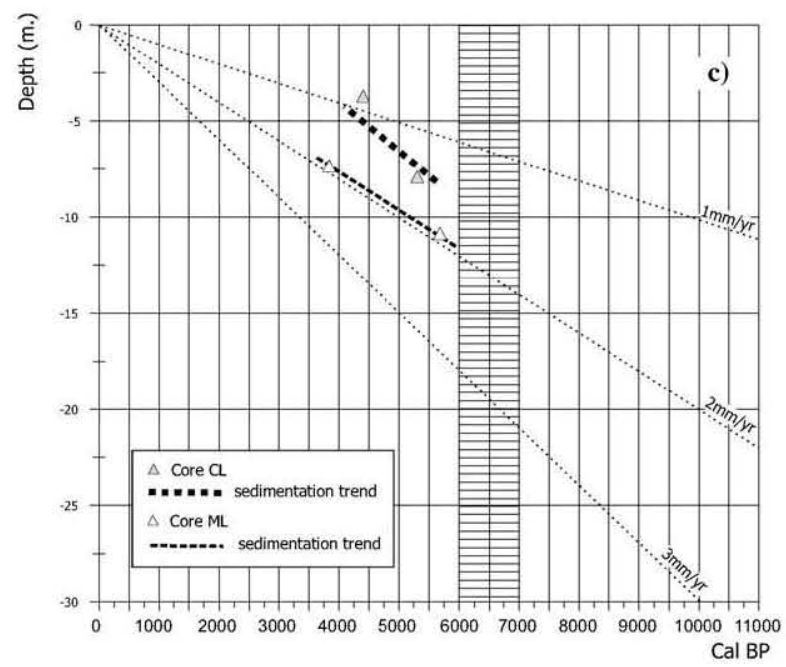

Guadelete estuary

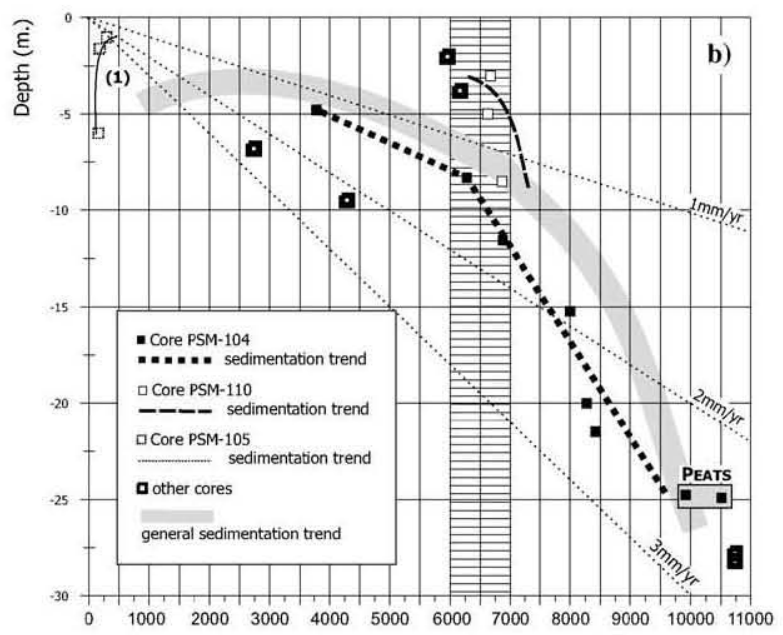

(1) Reworked samples showing negative rates related with erosional phases. Cal BP

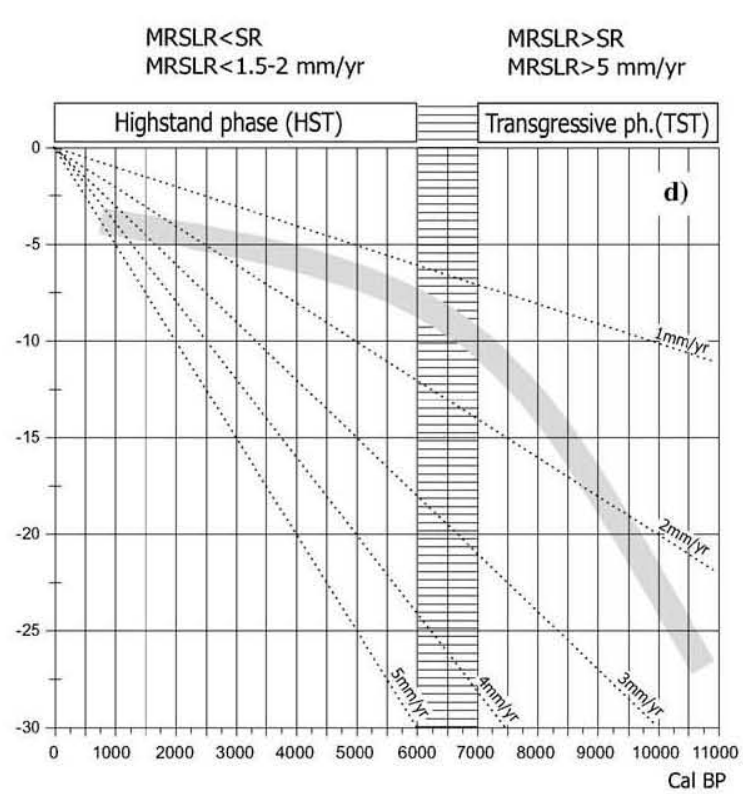

Fig. 2. Sedimentation rates and trends deduced for Holocene estuarine sequences: (a) Tinto-Odiel estuary; (b) Guadalete estuary; (c) Guadalquivir estuary; (d) general trend.

presumable stabilisation following the transgressive maximum.

\section{Guadalete estuary}

Data from Guadalete marshland comes from 11 drill cores described by Goy et al. (1996), Lario (1996) and Dabrio et al. $(1995,1999,2000)$ where the Late Pleistocene Holocene sequence is well exposed. Cores PSM-104 in the centre of the Holocene estuary, and PSM-110 (Fig. 2b) yielded the most continuous sets of data. The top of the underlying paleotopography generated during the Last Glacial has been situated at a depth of $28 \mathrm{~m}$ at this locality. A peat layer at a depth of $25 \mathrm{~m}$ records a stop or deceleration in the sea-level rise at ca. $10,500 \mathrm{Cal} \mathrm{BP}$. Since then until ca. $6500 \mathrm{Cal} \mathrm{BP}$ rates of sea-level rise accelerated (Goy et al. 1996; Lario, 1996; Dabrio et al., 1999, 2000).

Sedimentation rates calculated using the depth/age diagram are $5 \mathrm{~mm} / \mathrm{yr}$ (Fig. 2b), indicating rates of sealevel rise higher than these data. After ca. $6500 \mathrm{Cal} \mathrm{BP}$ values of vertical sedimentation rates decreased abruptly to $11.5 \mathrm{~mm} / \mathrm{yr}$. This can be explained as reflecting a change in sedimentation trend from mainly aggradational to progradational, and suggests rates of sea-level rise lower than this value, in agreement with essentially still-stand conditions found during the highstand. These 
data support the values of sea level-rise rates calculated by Dabrio et al. (2000).

Data from core PSM-105, located in the bed of the river San Pedro, show an inversion in radiocarbon data represented by negative values of sedimentation rates. This will be explained by sample reworking related to erosion and incision of the fluvial/tidal channel system taking place in the last 400 years, and interpreted as a result of anthropogenic factors (changes in cultivation methods and deforestation) and also climatic factors (increase in torrential rains, major floods and other catastrophic events) (Borja, 1992; Brückner and Hoffman, 1992; Lario et al., 1995).

\section{Guadalquivir estuary}

Radiocarbon dates from samples in cores of the Guadalquivir estuary (Zazo et al., 1999) cover only the last 6000 years, inside the highstand phase (Fig. 2c). The low values of sedimentation rates obtained (lower than $2.5 \mathrm{~mm} / \mathrm{yr}$ ) are consistent with those postulated for the still-stand conditions. Nevertheless, it is obvious that we need more radiocarbon data to refine these figures.

\section{Conclusions}

Because the sedimentation in estuaries is not homogeneous and synchronous in the entire basin, analyses of sedimentation rates using data from cores should be done separately for each core. Despite some local variations in the sedimentation rates, the present analysis proves that sedimentation rates in Holocene estuarine sequences of SW Spain followed two evident trends (Fig. 2d).

A first phase, between ca. 10,000 and $6500 \mathrm{Cal} \mathrm{BP}$ (i.e. the transgressive phase), with sedimentation rates of $5 \mathrm{~mm} / \mathrm{yr}$ was characterised by aggradation in the estuarine basin, with significant contribution from distal deposits of prograding bay-head deltas and fine-grained marine sediments.

The second phase extends after the transgressive maximum, between ca. $6500 \mathrm{Cal} \mathrm{BP}$ and present, (i.e., during the highstand phase), with rates of sedimentation lower than $2 \mathrm{~mm} / \mathrm{yr}$, and prevailing centripetal progradation of morpho-sedimentary systems (Goy et al., 1996). Rates of sea-level rise during the transgressive phase were higher than $5 \mathrm{~mm} / \mathrm{yr}$, while during the highstand phase the sea has been almost stable, with rates of sea-level rise lower than $1.5 \mathrm{~mm} / \mathrm{yr}$. These results demonstrate that the rate of sea-level rise decreased after $6500 \mathrm{Cal} \mathrm{BP}$, when the rate of sedimentation input in the estuaries surpassed the rate of sea-level rise, as postulated by Dabrio et al. (2000).

\section{Acknowledgements}

This work has been supported by the Spanish DGES Projects PB98-0514 and PB98-0265 and Fundación Areces Project "Climatic Changes and sea level changes". It is a contribution to IGCP 437 Project and INQUA Commission on Sea-level changes. J. Lario was supported by a grant from Comunidad de Madrid.

\section{References}

Bard, E., 1988. Correction of accelerator mass spectrometry ${ }^{14} \mathrm{C}$ ages measured in planktonic foraminifera: Paleoceanographic implications. Paleoceanography 3, 635-645.

Borja, F., 1992. Cuaternario reciente, Holoceno y periodos históricos del SW de Andalucia. Paleogeografía de medios litorales y fluviolitorales de los últimos 30.000 años. Unpublished Ph.D. Thesis, Universidad de Sevilla, $469 \mathrm{pp}$.

Borrego, J., Ruiz, F., González-Regalado, M.L., Pendón, J.G., Morales, J.A., 1999. The Holocene transgression into the estuarine central basin of the Odiel River mouth (Cadiz gulf, SW Spain): lithology and faunal assemblages. Quaternary Science Reviews 18, $769-788$.

Brückner, H., Hoffman, G., 1992. Human-induced erosion processes in Mediterranean countries. Evidences from archaeology, pedology and geology. Geoökoplus 3, 97-110.

Dabrio, C.J., Goy, J.L., Lario, J., Zazo, C., Borja, F., González, A., 1995. The Guadalete estuary during the Holocene times (Bay of Cadiz, Spain). INQUA Mediterranean and Black Sea Shorelines Subcommission Newsletter 17, 19-22.

Dabrio, C.J., Zazo, C., Lario, J., Goy, J.L., Sierro, F.J., Borja, F., González, J.A., Flores, J.A., 1999. Sequence stratigraphy of Holocene incised-valley fills and coastal evolution in the Gulf of Cádiz (southern Spain). Geologie en Mijnbouw 77, 263-281.

Dabrio, C.J., Zazo, C., Goy, J.L., Sierro, F.J., Borja, F., Lario, J., González, J.A., Flores, J.A., 2000. Depositional history of estuarine infill during the Late Pleistocene-Holocene postglacial transgression. Marine Geology 162, 381-404.

Goy, J.L., Zazo, C., Dabrio, C.J., Lario, J., Borja, F., Sierro, F., Flores, J.A., 1996. Global and regional factors controlling changes of coastlines in southern Iberia during the Holocene. Quaternary Science Reviews 15 (3-4), 1-8.

Harkness, D.D., 1983. The extent of natural ${ }^{14} \mathrm{C}$ deficiency in the coastal environment of the United Kingdom. In: Mook, W.G., Waterbolk, H.T. (Eds.), Proceedings of the First International Symposium ${ }^{14} \mathrm{C}$ and Archaeology. PACT 8, 351-364.

Lario, J., 1996. Último y Presente Interglacial en el área de conexión Atlántico-Mediterráneo: Variaciones del nivel del mar, paleoclima y paleoambientes. Unpublished Ph.D. Thesis. Universidad Complutense de Madrid, $269 \mathrm{pp}$.

Lario, J., Zazo, C., Dabrio, C.J., Somoza, L., Goy, J.L., Bardaji, T. Silva, P.G., 1995. Record of recent Holocene sediment input on spit bars and deltas of south Spain. In: Core, B. (Ed.), Holocene Cycles: Climate, Sea Levels, and Sedimentation. Journal of Coastal Research, Special Issue, 17, 241-245.

Nichols, M.M., Biggs, R.R., 1980. Estuaries. In: Davis, R. (Ed.), Coastal Sedimentary Environments. Springer, Berlin, pp. 77-185.

Pendón, J.G., Morales, J.A., Borrego, J., Jiménez, I., Lopez, M., 1998. Evolution of estuarine facies in a tidal channel environment SW Spain: evidence for a change from tide-to wave-domination. Marine Geology 147, 43-62.

Rodríguez-Ramírez, A., Rodríguez-Vidal, J., Cáceres, L., Clemente, L., Belluomini, G., Manfra, L., Improta, S., De Andrés, J.R., 1996. 
Recent coastal evolution of the Doñana National Park (SW Spain). Quaternary Science Reviews 15 (8-9), 803-809.

Roy, P.S., Cowell, P.J., Ferland, M.A., Thom, B.G., 1994. Wavedominated coasts. In: Carter, R.W.G., Woodroffe, C.D. (Eds.), Coastal evolution: Late Quaternary shoreline morphodinamics. Cambridge University Press, Great Britain, pp. 121-186.

Siani, G., Paterne, M., Arnold, M., Bard, E., Metivier, B., Tisnerat, N., Bassinot, F., 2000. Radiocarbon reservoir ages in the Mediterranean Sea and Black Sea. Radiocarbon 42 (2), 271-280.

Southon, J.R., Nelson, D.E., Vogel, J.S., 1990. A record of past oceanatmosphere radiocarbon differences from northeast pacific. Paleoceanography 5 (2), 197-206.

Stuiver, M., Reimer, P., 1993. Extended ${ }^{14} \mathrm{C}$ data base and revised CALIB $3.0{ }^{14} \mathrm{C}$ calibration program. In: Stuiver, M., Long, A., Kra, R.S. (Eds.), Calibration 1993. Radiocarbon 35, 231-237.

Stuiver, M., Pearson, G.W., Brazunias, T., 1986. Radiocarbon age calibration of marine shells back to $9000 \mathrm{cal}$ BP. Radiocarbon 28 , 980-1021.
Stuiver, M., Reimer, P.J., Bard, E., Beck, J.W., Burr, G.S., Hughen, K.A., Kromer, B., McCormac, F.G., v.d. Plicht, J., Spurk, M., 1998. INTCAL98 Radiocarbon Age Calibration, 24,000-0 cal BP. Radiocarbon 40, 1041-1083.

Zazo, C., Goy, J.L., Lario, J., Silva, P.G., 1996. Littoral zone and rapid climatic changes during the last 20,000 years, The Iberian study case. Zeitschrift fuer Geomorphologie N.F. 102, 119-134.

Zazo, C., Goy, J.L., Somoza, L., Dabrio, C.J., Belluomini, G., Improta, S., Lario, J., Bardaji, T., Silva, P.G., 1994. Holocene sequence of relative sea level highstand-lowstand in relation to the climatic trends in the Atlantic-Mediterranean linkage coast: forecast for future coastal changes and hazards. Journal of Coastal Research 10 (4), 933-945.

Zazo, C., Dabrio, C.J., González, J., Sierro, F., Yll, E.I., Goy, J.L., Luque, L., Pantaleón-Cano, J., Soler, V., Roure, J.M., Lario, J., Hoyos, M., Borja, F., 1999. The records of the later glacial and interglacial periods in the Guadalquivir marshlands (Mari López drilling, SW Spain). Geogaceta 26, 119-122. 